\title{
Potensi serangga pengunjung bunga sebagai vektor penyakit darah bakteri (Ralstonia solanacearum Phylotipe IV) pada pisang di Sumatera Barat
}

\author{
The potential of flower-visiting insects as a vectors blood disease \\ bacterium (Ralstonia solanacearum Phylotype IV) \\ on bananas in West Sumatera
}

\author{
Mairawita $^{1 *}$, Trimurti Habazar ${ }^{2}$, Ahsol Hasyim ${ }^{3}$, Nasril Nasir ${ }^{4}$, Suswati $^{5}$ \\ ${ }^{1}$ Jurusan Biologi, FMIPA, Universitas Andalas Universitas Andalas, \\ Kampus Unand Limau Manis, Padang 25163 \\ ${ }^{2}$ Program Studi Hama dan Penyakit Tanaman, Pascasarjana, Universitas Andalas. \\ Kampus Unand Limau Manis, Padang 25163 \\ ${ }^{3}$ Balai Penelitian Tanaman Sayuran Lembang. \\ Jalan Tangkuban Perahu No. 517 Lembang, PO Box 8413, Bandung 40391 \\ ${ }^{4}$ Program Studi Biologi, Pascasarjana, Universitas Andalas. \\ Kampus Unand Limau Manis, Padang 25163 \\ ${ }^{5}$ Program Studi Agroteknologi, Fakultas Pertanian, Universitas Medan Area, \\ Medan 20223
}

(diterima Maret 2012, disetujui April 2012)

\begin{abstract}
ABSTRAK
Penyakit darah (Blood disease bacteria (BDB)) yang disebabkan oleh Ralstonia solanacearum Phylotipe IV merupakan penyebab utama kehilangan hasil pisang di Indonesia. Khusus untuk daerah Sumatera Barat, informasi tentang keanekaragaman serangga dan potensinya sebagai vektor $R$. solanacearum Phylotype IV di Sumatera Barat belum tersedia. Tujuan penelitian ini adalah untuk memperoleh data keanekaragaman serangga dan peranannya sebagai agen penyebar $R$. solanacearum Phylotipe IV di Sumatera Barat. Penelitian ini dilakukan dengan metode purposive sampling di (a) dataran tinggi Tabek Panjang, Kecamatan Baso, Kabupaten Agam dan (b) dataran rendah Pasar Usang, Kecamatan Batang Anai, Kabupaten Padang Pariaman, Sumatera Barat. Hasil penelitian menunjukkan bahwa pada tanaman pisang yang terserang $R$. solanacearum Phylotipe IV memiliki keanekaragaman serangga pengunjung bunga. Keanekaragaman serangga lebih tinggi di dataran rendah dibanding di dataran tinggi dan didominasi Trigona spp. (Hymenoptera: Apidae) dan Drosophila sp. (Diptera: Drosophilidae). Serangga dari kedua kelompok tersebut berpotensi sebagai vektor $R$. solanacearum Phylotipe IV di Sumatera Barat. Isolasi dan identifikasi bakteri dari serangga pengunjung bunga tanaman pisang sakit dilakukan dengan metode Cahyaniati et al., (1997) dengan medium triphenyl tetrazolium chlorid (TTC) (Baharuddin 1992). Hasil identifikasi dari bakteri yang didapatkan pada serangga pengunjung bunga adalah R.solanacearum Phylotipe IV. Hasil ini menunjukkan bahwa serangga pengunjung bunga berpotensi menjadi vektor penyakit darah bakteri.
\end{abstract}

Kata kunci: blood disease bacteria, Ralstonia solanacearum Phylotipe IV, vektor, Trigona spp., Drosophila sp.

\footnotetext{
* Penulis korespondensi: Mairawita. Jurusan Biologi, FMIPA, Universitas Andalas Universitas Andalas, 


\begin{abstract}
Blood diseases caused by Ralstonia solancearum Phylotype IV is a major cause of production loss of banana in Indonesia, particularly for areas in West Sumatera. Currently there is a lack of information on blood diseases. The objective of this study was to obtain data of insect diversity and its potential as a dissemination agent of $R$. solanacearum Phylotype IV in West Sumatera. This research was conducted with a purposive sampling method in the Tabek Panjang highlands, District of Baso, Agam Regency and Pasar Usang lowland, district of Batang Anai, Pariaman Regency, West Sumatera. The results showed that banana plants infected by $R$. solanacearum Phylotype IV have a high diversity of flower-visiting insects. The diversity of insects in the lowlands is higher than that in highland and mainly are dominated by Trigona spp. (Hymenoptera: Apidae), Drosophila sp. (Diptera: Drosophilidae). To test the potential of both insect as vector of the blood diseases, isolated and identification of the bacteria using triphenyl tetrazolium medium chlorid (TTC) was used. Result showed that bacteria isolated from both insect are $R$. solanacearum hence providing evidence of the insect as vector of the blood diseases. Both insects have the potential to be vector of $R$. solanacearum Phylotype IV in West Sumatera. The identification of the bacteria that causes the disease. The identification of bacteria that is spread by flower visitors insects are R.solanacearum Phylotipe IV.
\end{abstract}

Key words: blood disease bacterium, $R$. solanacearum Phylotype IV, insect vector, Trigona spp., Drosophila sp.

\section{PENDAHULUAN}

Penyakit darah bakteri yang disebabkan oleh $R$. solanacearum Phylotipe IV menempati urutan pertama dalam daftar prioritas penyakit tanaman pisang di Indonesia (Valmayor et al. 1991) dan bersifat mematikan dengan menginfeksi jaringan pembuluh secara sistemik (Eden-Green 1992). Perkembangan dan penyebaran penyakit ini tergolong sangat cepat. Penyebaran geografis penyakit ini di Indonesia sekitar $100 \mathrm{~km}$ per tahun (Eden-Green 1994) dan di Sumatera berkisar antara 189-203 $\mathrm{km}$ per tahun (Setyobudi \& Hermanto 1999). Sampai saat ini, semua varietas tanaman pisang dapat terserang. Perkembangan dan penyebaran penyakit darah yang cepat ditengarai melibatkan peranan serangga (INIBAP 1995).

Beberapa peneliti melaporkan adanya indikasi yang kuat bahwa serangga berperan penting dalam penyebaran penyakit darah bakteri (Maryam et al. 1994 Soguilon et al. 1995; Setyobudi \& Hermanto 1999). Jenis serangga pengunjung bunga yang diduga sebagai vektor penyakit darah bakteri yaitu Diptera (Chloropidae, Platypezidae, Drosophilidae) (Suprijadi 1997) dan Lepidoptera (Erionota thrax) (Subandiyah et al. 2006). Trigona sp. (Hymenoptera: Apidae), Polybia sp. (Hymenoptera: Vespidae) dan Drosophila sp. (Diptera: Drosophilidae). Serangga-serangga tersebut dilaporkan sering mengunjungi bunga pisang yang terserang penyakit layu dan diduga berperan dalam penyebaran penyakit Moko (strain SFR) (Buddenhagen \& Elsasser 1962). Menurut Leiwakabessy (1999), Trigona spp. merupakan vektor penyakit darah di pertanaman pisang di Lampung.

Di pusat pertanaman pisang di Uganda yang terserang berat oleh Xanthomonas campestris pv. musacearum $(\mathrm{Xcm})$ ditemukan berbagai jenis serangga pengunjung bunga yang diduga berperan sebagai vektor $X$. campestris (Tushemereirwe et al. 2003). Beberapa jenis serangga dari Famili Apidae, Vespidae (Hymenoptera) dan Lonchaeidae, Muscidae, Tephritidae (Diptera) ditemukan sebagai vektor penyakit layu Xanthomonas pada pisang di Ethiopia (Shimelash et al. 2008). Kelompok serangga vektor sering ditemukan pada bunga jantan dan bunga betina tanaman sakit maupun sehat (Eden-Green 2004). Kelompok stingless bee (Plebeina denoiti) dan jenis Apidae yang belum terindentifikasi dilaporkan berperan sebagai vektor $X$. campestris dan jumlah koloni bakteri tertinggi ditemukan pada serangga yang mengunjungi bunga pisang yang terjangkit $X$. campestris dibanding bunga yang sehat (Tinzaara et al. 2006).

Sampai sejauh ini belum ada informasi mengenai keanekaragaman serangga penyerbuk dan peranannya sebagai vektor $R$. solanacearum 
Phylotipe IV pada tanaman pisang yang terserang penyakit darah bakteri di Sumatera Barat. Penelitian ini bertujuan untuk mengetahui jenis-jenis serangga pengunjung bunga yang berasosiasi dengan tanaman pisang yang terinfeksi $R$. solanacearum Phylotipe IV.

\section{BAHAN DAN METODE}

\section{Waktu dan tempat penelitian}

Penelitian dilakukan di daerah endemik penyakit darah bakteri pada ketinggian yang berbeda yaitu a) dataran rendah Pasar Usang (Kecamatan Batang Anai, Padang Pariaman) ; dan b) dataran tinggi Tabek Panjang (Kecamatan Baso, Kabupaten Agam), pada bulan FebruariDesember 2008. Identifikasi serangga pengunjung bunga dilakukan di Laboratorium Taksonomi Hewan, Jurusan Biologi, Fakultas Matematika dan Ilmu Pengetahuan Alam, Universitas Andalas, sedangkan untuk isolasi bakterinya dilakukan di Laboratorium Mikrobiologi, Fakultas Pertanian, Universitas Andalas.

Kriteria penentuan berdasarkan pada perbedaan ketinggian tempat, yaitu i) dataran rendah Nagari Pasar Usang (21 m dpl), Kecamatan Batang Anai, Kabupaten Padang Pariaman Pasar Usang; dan ii) dataran tinggi Tabek Panjang (876 m dpl), Kecamatan Baso, Kabupaten Agam. Pengamatan dilakukan di tiga kebun pisang yaitu 1 kebun (Kebun I) di dataran rendah dan 2 kebun di dataran tinggi (Kebun II dan Kebun III). Tanaman pisang di kebun I dan kebun II telah sekali panen dan di kebun III tanaman sedang berbunga. Luas kebun berkisar 1000-3000 m² (populasi 100-300 rumpun). Jumlah tanaman yang dijadikan sampel untuk pengambilan serangga ditetapkan masingmasing 10 tanaman sehat dan tanaman sakit yang berbunga/buah. Persentase kelimpahan relatif dihitung pada masing-masing lokasi pengamatan dengan rumus (Magurran 1987):

$$
\mathrm{KR}_{\mathrm{i}}=\mathrm{n}_{\mathrm{i}} / \mathrm{N} \times 100 \%
$$

dengan $n_{\mathrm{i}}$ : jumlah individu pada i jenis; $\mathrm{N}$ : jumlah individu

\section{Pengkoleksian serangga pengunjung bunga}

Serangga pengunjung bunga pisang dikumpulkan dengan metode penangkapan langsung dengan jaring serangga. Pengumpulan serangga dilakukan dari bunga jantan dan bunga betina. Serangga yang diperoleh dimasukkan ke botol racun yang berisi kloroform selama 1 menit untuk melemaskan serangga. Setiap individu serangga untuk setiap jenisnya dimasukkan ke masing-masing botol yang berisi akuades steril (untuk isolasi bakteri).

\section{Identifikasi serangga}

Identifikasi serangga sampai tingkat spesies memakai buku acuan Nakane (1955), Inoue et al. (1990), Sakagami et al. (1990), dan Borror et al. (1992).

\section{Isolasi R. solanacearum Phylotipe IV}

R. solanacearum Phylotipe IV diisolasi dari permukaan dan bagian dalam tubuh serangga dengan metode Cahyaniati et al. (1997) dengan medium triphenyl tetrazolium chlorid (TTC) (Baharuddin 1994).

\section{Isolasi $R$. solanacearum Phylotipe IV dari bagian luar tubuh serangga}

Untuk isolasi dari permukaan tubuh serangga, diambil satu individu serangga (dari famili yang berbeda) kemudian dimasukkan ke dalam tabung reaksi yang berisi $10 \mathrm{ml}$ akuades steril, kemudian divortex $300 \mathrm{rpm}$ selama 10 detik. Dilakukan pengulangan sebanyak tiga kali. Selanjutnya diencerkan secara serial $\left(10^{-1}, 10^{-3}, 10^{-6}, 10^{-9}\right)$. Air bilasan $1 \mathrm{ml}$ dari setiap pengenceran $1 \mathrm{ml}$ kemudian dimasukkan ke dalam tabung reaksi dan divortex selama 10 detik, kemudian dituang ke dalam cawan petri dan ditambah media TTC, diinkubasikan pada suhu ruang $\left( \pm 29^{\circ} \mathrm{C}\right)$ selama 48-72 jam. Kegiatan di atas dilakukan terhadap semua jenis serangga yang diperoleh.

\section{Isolasi $R$. solanacearum Phylotipe IV dari bagian dalam tubuh serangga}

Jaringan tubuh serangga yang disimpan dalam tabung eppendorf didesinfeksi dengan larutan natrium hipoklorit 5\% selama 5 menit, kemudian dibilas sebanyak 4-5 kali dengan air steril untuk menghilangkan sisa-sisa natrium hipoklorit. Serangga dikering anginkan terlebih dahulu dengan cara meletakkan tubuh serangga di atas kertas saring. Tubuh serangga dimasukkan ke dalam lumpang porselen kemudian ditambah $10 \mathrm{ml}$ akuadest steril dan selanjutnya digerus hingga semua bagian 
tubuh serangga hancur. Dilakukan pengenceran serial $\left(10^{-1}, 10^{-3}, 10^{-6}, 10^{-9}\right)$, diambil $1 \mathrm{ml}$ suspensi tubuh serangga dimasukkan kedalam cawan petri dan ditambah media TTC, diinkubasi pada suhu ruang $\left( \pm 29^{\circ} \mathrm{C}\right)$ selama $48-72 \mathrm{jam}$. Kegiatan di atas dilakukan terhadap semua jenis serangga yang diperoleh.

\section{Identifikasi R. solanacearum Phylotipe IV}

Isolat bakteri yang diperoleh diuji pertumbuhannya pada medium selektif TTC, diinkubasi pada suhu ruang $29^{\circ} \mathrm{C}$ selama $48-72 \mathrm{jam}$. Identifikasi dilakukan terhadap sifat morfologi koloni bakteri pada medium TTC ( 3 hsi) meliputi bentuk, ukuran, bentuk pinggiran, warna, bentuk permukaan dan sifat fisiologi bakteri (uji Gram, uji pektinase, uji Hypersensitif dan uji patogenisitas).

\section{HASIL}

\section{Keanekaragaman serangga pengunjung bunga}

Terdapat perbedaan keanekaragaman dan kelimpahan serangga yang mengunjungi bunga pisang di dataran tinggi dan dataran rendah. Keanekaragaman serangga pengunjung bunga lebih tinggi ditemukan di dataran rendah dibanding di dataran tinggi. Di dataran rendah ditemukan 4 ordo dengan 5 famili serangga, yaitu Hymenoptera (Apidae dan Formicidae), Lepidoptera (Hesperidae), Diptera (Drosophilidae) dan Hemiptera, sementara di dataran tinggi hanya ditemukan 3 ordo dengan 3 famili serangga, yaitu Hymenoptera (Apidae), Lepidoptera (Hesperiidae) dan Diptera (Drosophilidae) (Tabel 1 dan Gambar 1).
Jenis-jenis serangga pengunjung bunga tanaman pisang tersebut adalah: Trigona spp. (stingless bee) atau yang lebih dikenal "galo-galo", Apis dorsata, A. cerana (Hymenoptera: Apidae), Drosophila sp. (Hymenoptera: Drosophilidae), Oecophylla smaragdina (Hymenoptera: Formicidae), Erionota thrax (Lepidoptera: Hesperiidae), dan Nezara viridula (Hemiptera: Pentatomidae). Persentase kelimpahan Drosophila sp. dan Trigona spp. ditemukan dalam jumlah banyak pada bunga tanaman pisang di dua daerah ketinggian Sumatera Barat dengan urutan: Drosophila sp. (47,06\%); Trigona spp. (33,24\%); A. dorsata $(8,8 \%)$; A. cerana $(3,84 \%)$, E. thrax $(3,20 \%)$; Oecophylla smaragdina $(3,06 \%)$ dan Nezara viridula $0,80 \%$ (Gambar 2).

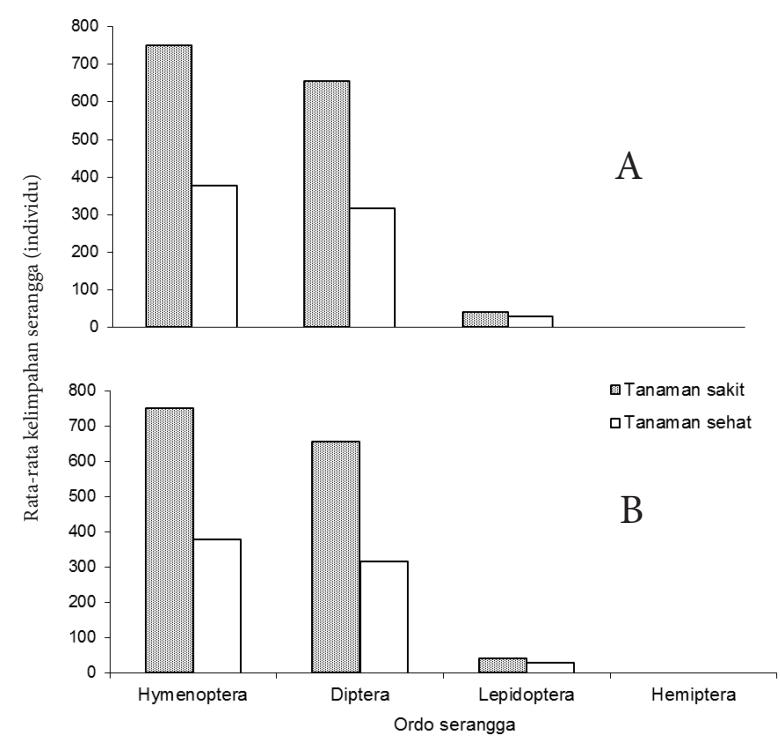

Gambar 1. Keanekaragaman serangga pada bunga tanaman pisang sehat dan sakit di Sumatera Barat. A: dataran tinggi; B: dataran rendah

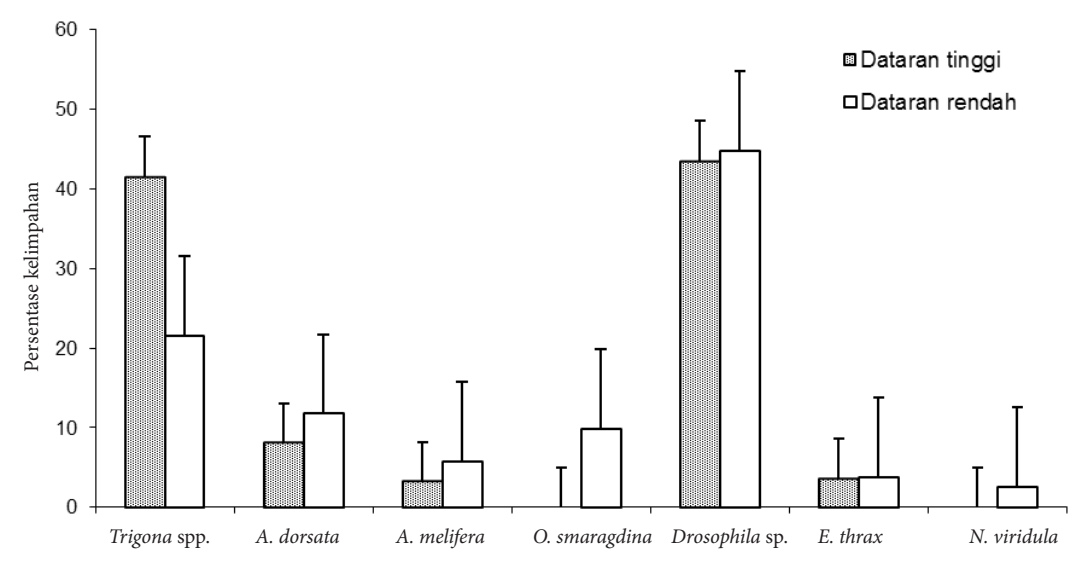

Gambar 2. Persentase kelimpahan serangga yang mengunjungi bunga pisang di daerah ketinggian berbeda 
Tabel 1. Keanekaragaman kelimpahan serangga pengunjung bunga yang berasosiasi dengan tanaman pisang sehat di lahan endemik penyakit darah bakteri pada ketinggian yang berbeda (Juni-Desember 2008). BB: Bunga Betina; BJ: Bunga Jantan

\begin{tabular}{|c|c|c|c|c|c|c|c|c|c|c|}
\hline \multirow{5}{*}{$\begin{array}{l}\text { Ordo } \\
\qquad \begin{array}{l}\text { Famili } \\
\text { Spesies }\end{array}\end{array}$} & \multirow{2}{*}{\multicolumn{3}{|c|}{$\frac{\text { Dataran rendah }}{\text { Kebun I }}$}} & \multicolumn{5}{|c|}{ Dataran tinggi } & & \multirow{4}{*}{ Total } \\
\hline & & & & \multicolumn{3}{|c|}{ Kebun II } & \multicolumn{3}{|c|}{ Kebun III } & \\
\hline & \multirow{2}{*}{$\begin{array}{c}\begin{array}{c}\text { Tanaman } \\
\text { sehat }\end{array} \\
\text { BB } \\
\end{array}$} & \multicolumn{2}{|c|}{$\begin{array}{c}\text { Tanaman } \\
\text { sakit }\end{array}$} & \multirow{2}{*}{$\begin{array}{c}\begin{array}{c}\text { Tanaman } \\
\text { sehat }\end{array} \\
\text { BB }\end{array}$} & \multicolumn{2}{|c|}{$\begin{array}{c}\text { Tanaman } \\
\text { sakit }\end{array}$} & \multirow{2}{*}{$\begin{array}{c}\begin{array}{c}\text { Tanaman } \\
\text { sehat }\end{array} \\
\text { BB } \\
\end{array}$} & \multicolumn{2}{|c|}{$\begin{array}{c}\text { Tanaman } \\
\text { sakit }\end{array}$} & \\
\hline & & $\mathrm{BJ}$ & $\mathrm{BB}$ & & $\mathrm{BJ}$ & BB & & $\mathrm{BJ}$ & $\mathrm{BB}$ & \\
\hline & \multicolumn{9}{|c|}{ individu/tanaman } & \\
\hline $\begin{array}{c}\text { Hymenoptera } \\
\text { Apidae }\end{array}$ & 226 & 118 & 315 & 190 & 165 & 359 & 188 & 177 & 391 & 2129 \\
\hline Trigona spp. & 80 & 35 & 175 & 135 & 150 & 311 & 115 & 145 & 300 & 1446 \\
\hline Apis dorsata & 50 & 33 & 75 & 20 & 10 & 45 & 40 & 25 & 85 & 383 \\
\hline A. cerana & 51 & 18 & 9 & 35 & 5 & 3 & 33 & 7 & 6 & 167 \\
\hline \multicolumn{11}{|l|}{ Formicidae } \\
\hline O. smaragdina & 45 & 32 & 56 & 0 & 0 & 0 & 0 & 0 & 0 & 133 \\
\hline \multicolumn{11}{|l|}{ Drosophilidae } \\
\hline Drosophila sp. & 245 & 97 & 494 & 152 & 128 & 300 & 165 & 111 & 355 & 2047 \\
\hline \multicolumn{10}{|l|}{ Hesperiidae } & 139 \\
\hline Erionota thrax & 34 & 11 & 5 & 5 & 5 & 4 & 25 & 15 & 35 & 139 \\
\hline \multicolumn{11}{|l|}{ Pentatomidae } \\
\hline Nezara viridula & 11 & 9 & 15 & 0 & 0 & 0 & 0 & 0 & 0 & 35 \\
\hline Total & 516 & 235 & 829 & 347 & 298 & 663 & 378 & 303 & 781 & 4350 \\
\hline Ordo & 4 & & 4 & 3 & & 3 & 3 & & 3 & \\
\hline Famili & 5 & & 5 & 5 & & 5 & 5 & & 5 & \\
\hline Spesies & 7 & & 7 & 7 & & 7 & 7 & & 7 & \\
\hline
\end{tabular}

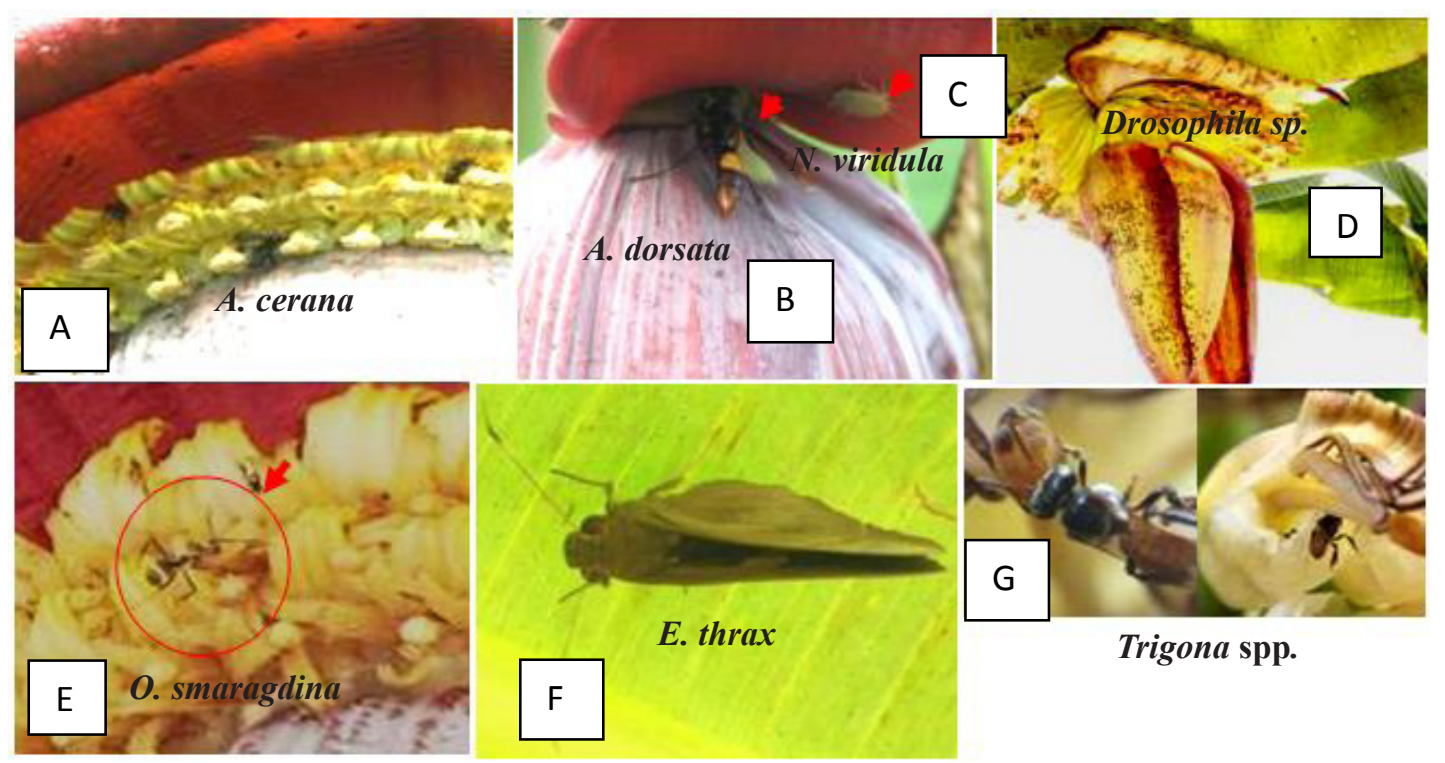

Gambar 3. Serangga pengunjung bunga yang diduga berperan sebagai vektor penyakit darah bakteri.

A: Apis cerana; B: A. dorsata; C: Nezara viridula; D: Drosopila sp.; E: Oecophylla smaragdina; F: Erionota thrax; G: Trigona spp.

Jumlah serangga yang mengunjungi bunga tanaman sakit lebih tinggi di banding bunga tanaman sehat di dua ketinggian tempat. Terjadi peningkatan persentase kelimpahan serangga yang mengunjungi bunga terinfeksi di dataran tinggi yaitu 2,76 kali (kebun II); 2,86 kali (kebun III) 

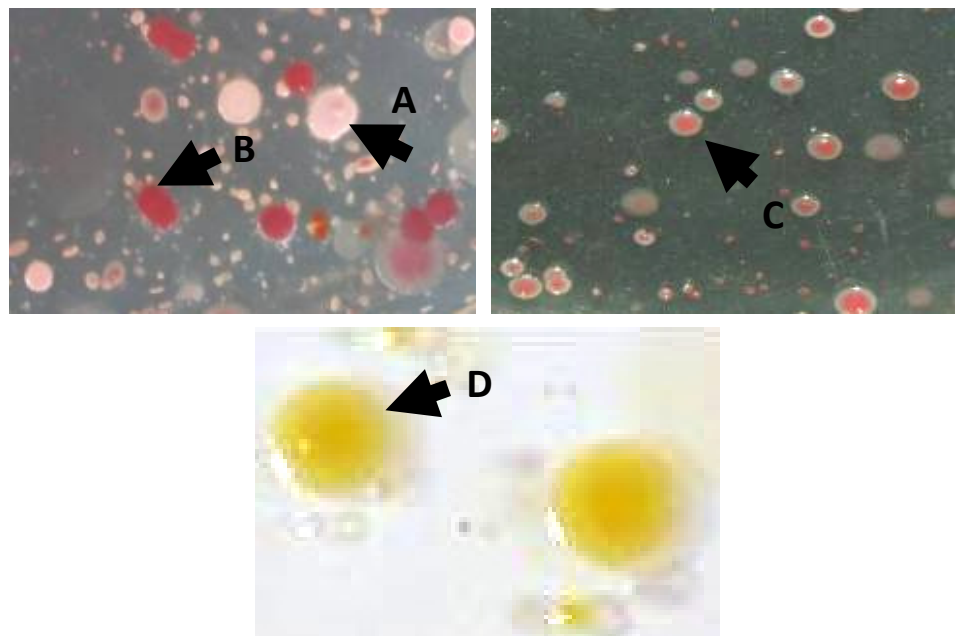

Gambar 4. Tipe morfologi isolat bakteri yang diisolasi dari serangga: A: koloni 1; B: koloni 2; C: koloni 3; D: koloni bakteri Xanthomonas sp.

Tabel 2. Karakter bakteri penyebab penyakit darah di dataran tinggi Tabek Panjang, Kecamatan Baso, Kabupaten Agam, Sumatera Barat

\begin{tabular}{lc}
\hline $\begin{array}{l}\text { Sifat morfologi dan } \\
\text { fisiologi }\end{array}$ & Ciri-ciri \\
\hline Bentuk koloni & $\begin{array}{c}\text { bulat, mukoid, fluidal } \\
\text { putih dengan/tanpa formasi } \\
\text { Warna koloni } \\
\text { merah muda } \\
\text { batang }\end{array}$ \\
Reaksi Gram & - \\
Pigmen fluorescens & - \\
Pektinase & + \\
Kovac's oksidase & + \\
Uji HR & + \\
Uji patogenisitas & + \\
\hline
\end{tabular}

dan di dataran rendah sebesar 2,06 kali (kebun I), sementara kelimpahan serangga pada bunga sehat lebih rendah yaitu 0,36 kali (kebun II), 0,34 kali (kebun III) dan 0,48 kali (kebun I) (Gambar 2). Pada umumnya kelimpahan serangga pada bunga betina lebih tinggi dibanding bunga jantan.

\section{Keberadaan bakteri pada serangga}

Propagul $R$. solanacearum Phylotipe IV dapat ditemukan pada permukaan dan bagian dalam tubuh serangga pengunjung bunga (Trigona spp., A. dorsata, A. cerana, E. thrax, O. smaragdina, $N$. viridula) yang dikoleksi pada tanaman pisang yang terserang $R$. solanacearum Phylotipe IV. Ditemukan 3 tipe koloni bakteri yang diduga $R$. solanacearum Phylotipe IV, yaitu koloni 1 berwarna merah menyala, ukuran 0,5-10 mm; cembung dan fluidal; koloni 2 berwarna pink, cembung dan fluidal dengan atau tanpa pusat formasi merah muda, tidak beraturan, berukuran 0,5-10 mm; dan koloni 3 berwarna merah cembung dan fluidal dengan atau tanpa pusat formasi merah muda, tidak beraturan, berukuran $0.5-10 \mathrm{~mm}$ (Gambar 4A, 4B, 4C). Selain itu ditemukan juga koloni bakteri Xanthomonas sp. (Gambar 4D). Koloni 1-3 memiliki karakter morfologi dan fisiologi tipikal bakteri penyebab penyakit darah $R$. solanacearum Phylotipe IV. Karakter tersebut dapat dilihat pada Tabel 2.

\section{PEMBAHASAN}

Keanekaragaman serangga pengunjung bunga lebih tinggi di dataran rendah dibanding dataran tinggi Sumatera Barat. Drosophilidae ditemukan dalam jumlah tinggi di dataran rendah. Banyaknya Drosophila sp. di dataran rendah tersebut dikarenakan pada tempat ini adalah sentra kebun buah-buahan rakyat terutama pepaya, nangka, kedondong dan buah-buahan lainnya yang banyak ditemukan sebagai media utamanya. Kelimpahan serangga tersebut jumlahnya 2 kali lebih banyak pada bunga jantan terinfeksi dibanding bunga jantan sehat. Tingginya populasi Drosophila sp. pada bunga tanaman sakit diduga karena serangga tertarik pada bau yang dikeluarkan oleh jaringan bunga/buah yang membusuk. Tingginya kelimpahan Drosophila sp. pada bunga tanaman sakit diduga karena serangga tertarik pada bau yang dikeluarkan bakteri pada jaringan bunga/buah yang membusuk (Robacker \& Garcia 1993). Pada 
Tephritidae, aroma buah terbukti sangat menarik serangga tersebut untuk meletakkan telur, makan dan kawin (Fletcher \& Prokopy 1991; Landolt et al. 1992).

Terjadinya perbedaan kelimpahan dari serangga pengunjung bunga tersebut juga disebabkan oleh berbagai faktor seperti jarak sarang ke sumber makanan, jumlah bunga, keadaan cuaca dan pengelolaaan tanaman. Menurut Morse dan Hooper (1985), sering atau tidaknya serangga pengunjung bunga mengunjungi sumber makanan ditentukan oleh banyak faktor diantaranya jarak sarang ke sumber makanan, jumlah bunga, keadaan cuaca, jumlah polinator yang mengunjungi sumber makanan dan jenis tanaman yang akan dikunjungi.

Saat mekarnya bunga betina atau bunga jantan merupakan kondisi kritis tanaman untuk terserang penyakit ini karena pada saat tersebut ditemukan jenis dan jumlah serangga pengunjung bunga dalam jumlah tinggi. Jumlah serangga yang mengunjungi bunga tanaman sakit lebih tinggi di banding bunga tanaman sehat di dua ketinggian tempat. Penelitian Shimelas et al. (2008) pada bunga pisang kultivar Kayinja (pisang Awak) yang terserang Banana Xanthomonas Wilt (BXW) yang disebabkan oleh Xanthomonas axonopodis pv. musacearum di distrik Mukono, Luwero dan Mpigi, Uganda menemukan serangga pengunjung bunga dalam jumlah tinggi dari famili Apidae (Plebeina denoiti (Vachal) stingless bee, lalat buah (Drosophilidae) dan grass flies (Chloropidae). Ketiga jenis serangga tersebut jumlahnya 4 kali lebih banyak pada bunga jantan tanaman yang terserang penyakit.

Kelimpahan serangga pengunjung bunga lebih tinggi pada varietas Kepok dibanding pada bunga varietas pisang lainnya. Disamping itu, faktor lingkungan terutama suhu dan kelembababan udara, sangat mempengaruhi keanekaragaman serangga. Suhu udara rata-rata Tabek Panjang berkisar $25,8-26,8^{\circ} \mathrm{C}$, RH $82-90 \%$, jumlah hujan $12,48-42,3 \mathrm{~mm}$ dan lama penyinaran $38-67 \%$, sedangkan di Pasar Usang suhu udara rata-rata adalah $28-29,6^{\circ} \mathrm{C}$ dengan $\mathrm{RH} \quad 80-87 \%, 12-20$ hari hujan (HH/bulan), lama penyinaran 35-63\% (BMKG 2007). Keadaan tersebut mendukung tingginya aktifitas serangga-serangga yang berperan sebagai polinator. Menurut Smith (1960) dalam Nismah (1983), aktifitas lebah berkorelasi positif dengan suhu dan kelembaban udara.
Puncak aktifitas terjadi pada suhu $17-27{ }^{\circ} \mathrm{C}$ dan RH $54-90 \%$.

Terdapat perbedaan peran dari masing-masing ordo terhadap penyebaran propagul bakteri. Pada pertanaman pisang di dataran tinggi, serangga pengunjung bunga yang berperan penting adalah dari Ordo Hymenoptera (Trigona spp, A. dorsata, A. cerana) dan Diptera (Drosophila sp.). Diduga bahwa dalam aktifitas mencari makan, serangga serangga terkontaminasi propagul bakteri, kemudian menyebarkannya ke tanaman pisang yang sehat. Menurut Tinzaara et al. (2006), serangga pada saat mencari makan akan terkontaminasi bakteri dan membawa bahan makanan yang mengandung propagul bakteri. Serangga mengisap cairan oose dari pelukaan akibat gugurnya bunga jantan atau seludang tanaman bergejala sering ditemukan di lapangan. Sel bakteri BXW telah diisolasi dari stingless bee (P. denoiti), lebah madu (A. melifera), dan lalat buah yang dikoleksi dari bunga jantan tanaman terserang dan tanaman sehat (Tinzaara et al. 2006). Pada pertanaman pisang Bluggoe yang terserang penyakit layu di Honduras ditemukan propagul $R$. solanacearum Phylotipe IV pada tubuh lebah dan tabuhan (Buddenhagen \& Elsasser 1962).

Tingginya kelimpahan Trigona spp. di tanaman pisang dataran tinggi disebabkan oleh sarangnya yang banyak di sekitar daerah penelitian, seperti pada dinding rumah penduduk, rongga pohon dan tiang-tiang bambu. Hal ini sesuai dengan pendapat Salmah (1992) bahwa T. minangkabau membuat sarang pada rongga batang pohon dan cabang pohon, tiang-tiang bambu, celah-celah dinding rumah dan rongga pada paku tiang. T. minangkabau adalah jenis galo-galo yang sering ditemui menempati berbagai habitat baik di hutan primer, hutan sekunder dan daerah pemukiman (Salmah et al. 1993). Faktor lain yang mendukung adalah kondisi lingkungan dan ketersediaan makanan dalam jumlah tinggi di sekitar daerah penelitian (Inoue et al. 1985; Suwarno 1992). Varley et al. (1978) menyatakan bahwa banyaknya serangga penyerbuk pada suatu habitat sangat ditentukan oleh kondisi lingkungan dan ketersediaan makanan.

Spesies lain dari famili Apidae yang ditemukan di tiga lokasi pengamatan adalah $A$. dorsata dan A. cerana. Kedua jenis lebah tersebut merupakan lebah yang cukup kuat dengan ukuran tubuh yang lebih besar dari galo-galo. Jumlah A dorsata 
dan A. cerana ditemukan lebih dari 1 individu pada saat berkunjung ke bunga jantan, serangga tersebut berpindah dengan cepat dari bunga jantan tanaman sakit ke bunga jantan dan bunga betina tanaman sehat. Mobilitas serangga ini tergolong tinggi, karena dapat berpindah dengan cepat dalam rangkaian bunga betina sebelum pindah ke bunga lainnya. Walaupun kelimpahan A. dorsata lebih rendah dibanding Trigona spp. tetapi karena mobilitasnya tinggi menyebabkan $A$. dorsata berpotensi besar sebagai agen penular darah bakteri. Menurut Daryanto dan Satifah (1984), satu individu A. dorsata dapat mengunjungi 100 bunga dalam satu perjalanan dan dapat mengangkut serbuk seberat $20 \mathrm{mg}$. Pada umumnya lebah pekerja mendatangi satu jenis tanaman yang sedang berbunga lebat berulangkali secara bersama-sama. Lebah pekerja ini berpindah dari satu bunga ke bunga yang lain sambil mengangkut serbuk sari. Jumlah bunga yang dikunjungi setiap hari berhubungan positif dengan ketersediaan nektar bunga (Giurta \& Nunez 1992).

Faktor lingkungan, terutama suhu, kelembaban dan intensitas penyinaran, akan mempengaruhi waktu ketersediaan dan kualitas polen dan nektar yang dihasilkan tumbuhan (Anderson et al. 1983). Suhu yang tinggi menyebabkan terjadinya proses kimia secara cepat dalam tubuh tumbuhan sehingga ketersediaan dan kualitas nektar yang tersedia lebih cepat dengan kualitas baik. Pernyataan tersebut disokong oleh Percual (1965) cit Adrial (1990), bahwa cahaya matahari akan menguapkan air nektar bunga sehingga konsentrasi gulanya meningkat. Konsentrasi gula nektar yang tinggi semakin disukai oleh lebah dan pada umumnya bunga jantan pisang genom B (Balbisiana) mengandung kadar gula tinggi (Setyobudi \& Hermanto 1999).

Propagul $R$. solanacearum Phylotipe IV penyebab penyakit darah bakteri berhasil diisolasi dari permukaan dan bagian dalam tubuh serangga pengunjung bunga pada tanaman pisang sakit. Bakteri tersebut berukuran 0,5-10 mm, cembung dan fluidal dengan atau tanpa pusat formasi merah muda dan tidak beraturan, menimbulkan gejala layu dan penguningan pada bibit pisang dengan masa inkubasi 3 hari setelah inokulasi dan menyebabkan jaringan nekrotik pada daun tembakau pada uji hypersensitif. Karakter ini sesuai dengan tipikal $R$. solanacearum Phylotipe IV. Menurut Baharudin (1994), koloni bakteri pada medium biakan TTC yang diinkubasi pada temperatur $28^{\circ} \mathrm{C}$ selama 72 jam berukuran 0,5 $4,5 \mathrm{~mm}$, tidak beraturan, cembung dan non-fluidal dengan atau tanpa formasi merah muda.

\section{KESIMPULAN}

Pada tanaman pisang yang terserang penyakit darah bakteri di dataran tinggi Tabek Panjang dan dataran rendah Pasar Usang ditemukan serangga yang berasosiasi dari 4 ordo (Hymenoptera, Diptera, Lepidoptera dan Hemiptera). Ordo yang tertinggi kelimpahannya adalah Diptera $(38,46 \%)$ diikuti ordo Hymenoptera sebesar $36,46 \%$. Ordo Hymenoptera didominasi Trigona spp. dan ordo Diptera didominasi Drosophila sp. Tingginya persentase serangan penyakit darah bakteri di dataran tinggi Tabek Panjang berhubungan erat dengan tingginya kelimpahan serangga pengunjung bunga Trigona spp. (galo-galo). Propagul bakteri ditemukan pada permukaan dan bagian dalam tubuh serangga pengunjung bunga tanaman pisang yang terserang penyakit darah bakteri di lahan endemik dataran tinggi Baso, Sumatera Barat. Hasil identifikasi bakteri tersebut adalah R. solanacearum Phylotipe IV.

\section{DAFTAR PUSTAKA}

Adrial. 1990. Aktifitas mencari makanan Apis cerana javana Fabr. Tesis. Padang: FMIPA Universitas Andalas

Baharuddin B. 1994. Pathological, biochemical and serological characterization of the blood disease bacterium affecting banana and plantain (Musa sp.) in Indonesia. Goettingen: Cuvillier Verlag.

BMKG. 2007. Badan meteorologi dan klimatologi geofisika. data cuaca, stasiun meteorologi tabing. Padang. 20 pp, Unpublished.

Borror DJ, Triphlehorn CA, Johson FN. 1992. Pengenalan pelajaran serangga. Yogyakarta: Gadjah Mada University Press.

Buddenhagen IW, Elsasser TA. 1962. An insect spread wild epiphytotic of bluggoe bananas. Nature 194:146-165.http://dx.doi.org/10.1038/194164a0.

Cahyaniati, Mortensen CN, Mathur SB. 1997. Bacterial wilt of banana in Indonesia. Jakarta: Directorate of Food Crops Protection. Indonesia 
and Danish Government Institute of Seed Pathology for Developing Countries. Denmark: Technical Bulletin.

Daryanto, Satifah S. 1984. Pengetahuan dasar biologi bunga dan teknik penyerbukan silang buatan. Jakarta: PT. Gramedia.

Eden-Green SJ. 1992. Characteristics of Pseudomonas solanacearum and related bacteria from banana and plantain in South East Asia. In: M. Lemattre, S. Freigoun, K. Rudolph and J.G Swings (Eds.), Plant Pathogenic Bacteria. pp. 51-57. IRNA.

Eden-Green SJ. 1994. Banana blood disease. Musa Disease Fact Sheet No.3. 2p. France: INIBAP, Montpellier.

Eden-Green SJ. 2004. How can the advance of banana Xanthomonas Wilt be halted? Info Musa 13:38-41.

Fletcher BS, Prokopy RJ. 1991. Host location and oviposition in tephritid fruit flies. In: W. J. Bailey and J. Ridsdill-Smith (Eds.), Reproductive Behaviour of Insects: Individuals and Populations. pp. 139-171. New York: Chapman and Hall

Giurta M, Nunez JA. 1992. Foraging by honey bee on Carduss acarthuides: pattern an efficiency (edit. M.Begon and DJ. Thomson). Published for the Royal Entomological Society of London Blackwell Scientific Publication Oxford 17:326330 .

INIBAP. 1995. IMTP Phase Technical Guidelines for Fusarium Wilt Sites. International Network for The Improvement of Banana Plantain.

Inoue T, Salmah S, Abbas I, Yusuf E. 1985. Foraging behavior of individual worker and foraging dynamic of colonies of three Sumateran stingless bee. Researches on Population Ecology 27:373-392. http://dx.doi.org/10.1007/BF02515474.

Inoue T, Salmah S, Sakagami SF, Yamane SK, Kato M. 1990. An analysis of Anthophilus insect in Central Sumatera. In: Sakagami SF, Ohgushi R, Roubik DW (Eds.), Natural History of Social Wasp and Bees in Equatorial Sumatera. Sapporo: Hokkaido University Press.

Landolt PJ, Reed HC, Heath RR. 1992. Attraction of female papaya fruit fly (Diptera: Tephritidae) to male pheromone and host fruit. Environmental Entomology 21:1154-1159.

Leiwakabessy C. 1999. Potensi beberapajenis serangga dalam penyebaran penyakit layu bakteri Ralstonia (Pseudomonas) solanacearum Yabuuchi et al. pada pisang di Lampung. Tesis. Bogor: Program Pascasarjana Institut Pertanian Bogor.

Maryam Abn, Tata Rasta O, Handayani W, Sihombing D. 1994. Beberapa jenis serangga pengunjung bunga pisang yang diduga sebagai penular penyakit layu bakteri (Pseudomonas solanacearum E.F. Smith) Di dalam: Prosiding Rapat Kerja Penyusunan Prioritas dan Desain Penelitian Hortikultura (Solok, 17-19 November). pp 4448 Solok: Balai Penelitian dan Pengembangan Pertanian, Pusat Penelitian dan Pengembangan Hortikultura.

Morse R, Hooper T. 1985. The illustrated encyclopedia of beekeeping. Sherborne U.K: Alphabooks.

Magurran AE. 1987. Ecological diversity and its measurement. London: Chapman and Hill.

Nakane T. 1955. Coloured ilustration of the insect of Japan. Vol.1. Osaka Japan : Hoikhusa Publishing Co. Ltd.

Nismah. 1983. Perkembangan koloni Galo-Galo Trigona (Tetragonula) laeviceps Smith. Tesis. Padang: FMIPA Universitas Andalas.

Robacker D, Garcia JA. 1993. Effects of age, time of day, feeding history, and gamma irradiation on attraction of Mexican fruit flies (Diptera: Tephritidae), to bacterial odor inlaboratory experiments. Environ Entomol. 22:1367-1374.

Sakagami SF, Inoue T, Yamane S and Salmah S. 1990. Stingless bees of central Sumatera. In: S.F. Sakagami, R. Ohgushi and D.W. Roubik (Eds.), Natural History of Social Wasps and Bees in Equatorial Sumatera, pp. 125-137. Sapporo: Hokkaido University Press.

Salmah S. 1992. Lebah. Di dalam: Pengembangan dan Pelestariannya. Pidato Pengukuhan Guru Besar Ilmu Biologi. Padang: Universitas Andalas. Salmah S, Abbas I dan Dahelmi. 1993. Jenis lebah (Apids Bees) dan kupu-kupu (Butterflies) di hutan pendidikan dan penelitian biologi. Laporan Penelitian. Padang: Pusat Penelitian Universitas Andalas.

Setyobudi L, Hermanto C. 1999. Rehabilitation of cooking banana farms; base line status of Banana Disease Bacterium (DARAH) distribution in Sumatera. In: A.B. Molina and V.N Roa (Eds.), Advancing Banana and Plantain R\&D in Asia and The Pasific. p117-120. Guangchou: Proc of the 9 th INIBAP-ASPNET Regional Advisory Committee Meeting.

Shimelash D, Alemu T, Addis T, Turyagyenda FL, Blomme G. 2008. Banana Xanthomonas 
Wilt in Ethiopia: occurrence and insect vector transmission. African Crop Science Journal 16:75-87.

Soguilon CE, Magnave LV, Natural MP. 1995. Bugtok disease of banana. Musa fact sheet No.5 France: INIBAP.

Subandiyah S, Martono E, Suharjo F. 2006. Potensi Erionatha thrax sebagai agen penyebar patogen penyebab penyakit layu bakteri pada tanaman pisang (blood disease bacterium). Tropika 6:100106.

Suprijadi JGE, Eden-Green S.J, Mansfield, JM. 1997. Bacteriophage typing of Ralstonia solanacearum, Pseudomonas schyzigii and blood disease bacterium of banana. Hayati 4:72-74.

Suwarno. 1992. Aktifitas mencari makanan dan material sarang Trigona (Tetragona) apicalis Smith. Tesis. Padang: FMIPA Universitas Andalas.
Tinzaara W, Gold CS, Ssekiwoko F, Tushemeirwe W, Bandyopadhyay R, Eden-Green SJ. 2006. The possible role of insects in the transmission of Banana Xanthomonas Wilt. In: The 4th International Bacteria Wilt Symposium (UK, 1720 July) York, UK.

Tushemereirwe WK, Kangire A, Smith J, Ssekiwoko F, Nakyanzi M, Kataama D, Musiitwa C, Karyeija R. 2003. An outbreak of bacterial wilt on banana in Uganda. Infomusa 12:6-8.

Valmayor RV, Umali BE, Bejosano CP. 1991. Summary of discussion and recommendation of the INIBAP Brisbane Conference. 1-4. In: Banana Diseases in Asia and The Pasific. International Network for Asia and The Pasific. INIBAP.

Varley GC, Grad Well GR, Hassel MP. 1973. Insect population ecology and analytical approach. Oxford: Blackwell Scientific Publication. 